\title{
Fenomeno emozionalen eta sormenaren arteko erlazioak Psikologiaren ikuspegitik ${ }^{1}$
}

\author{
Goretti Soroa Martínez \\ Aitor Aritzeta Galán \\ Oinarrizko Prozesu Psikologikoen eta euren Garapenaren Saila \\ Psikologia Fakultatea \\ Euskal Herriko Unibertsitatea (UPV/EHU) \\ Nekane Balluerka Lasa \\ Gizarte Psikologiaren eta Portaera Zientzien Metodologia Saila \\ Psikologia Fakultatea \\ Euskal Herriko Unibertsitatea (UPV/EHU)
}

DOI: $10.1387 /$ tantak.14452

GAKO-HITZAK: Emozioak, sormena, psikologia, eredu teorikoak.

\section{SARRERA}

Egun arreta berezia jasotzen ari den ikerketa-lerroa da emozioen eta sormenaren arteko erlazioarena. Gainera, hezkuntza eta lan arloetan ikasle nahiz langileen eraginkortasuna areagotzearen gakoa gaitasun sozioemozionalak eta sortzaileak lantzean egon daitekeela uste da. Baina nola erlazionatzen dira fenomeno emozionalak eta sormena? Galdera horri erantzuna emateko asmoz, literatura zientifikoak gaiaren inguruan erakutsi dituen emaitza esanguratsuenak biltzen ditu lan honek. Lehen zatian, fenomeno emozionalen tonuak (positiboa edo negatiboa), aktibazio-mailak (altua, ertaina edo baxua) eta erregulazio-fokuak (promoziozkoa edo pre-

${ }^{1}$ Lan honek Euskal Herriko Unibertsitateko Euskararen arloko Errektoreordetzaren diru-laguntza jaso du, tesiak euskaraz egiteko doktorego aurreko ikertzaileak prestatzeko 2010ko deialdian.

Harremanetarako datuak: Goretti Soroa. Euskal Herriko Unibertsitatea. Psikologia Fakultatea. Oinarrizko Prozesu Psikologikoen eta euren Garapenaren saila. Tolosa hiribidea, 70. Donostia (20018). Posta elektronikoa: goretti.soroa@ehu.es. 
bentziozkoa) sormenarekin nola erlazionatzen diren aztertuko da. Bigarren zatian, fenomeno emozionalak eta sormena batera ikertzen dituzten eredu teoriko esanguratsuenak aurkezten dira eta barne hartzen dituzten dimentsioak definitzen dira. Azkenik, lan honetan zehar aztertutako edukietatik ateratako ondorio batzuk aurkezten dira.

\section{ZATIA: FENOMENO EMOZIONALEN ETA SORMENAREN ARTEKO ERLAZIOAK}

Sormenaren ikerketan badirudi alderdi kognitiboa nagusitu izan dela, alderdi emozionala alboratuta geratu den bitartean (ikus Soroa, Aritzeta eta Balluerka, 2012). Esaterako, sormenaren eredu teoriko ezberdinak uztartzen dituen definizio bateratuak ez ditu nortasun ezaugarriak, motibazioa eta emozioak aipatzen (Simonton, 2008): «Testuinguru zehatz baterako erabilgarria, berria eta hautemangarria den emaitza (produktua) eragiten duen pertsona batek, sortzerakoan (prozesua) martxan jartzen dituen trebezien (pertsona) eta kanpo-presioen (testuingurua) arteko interakzioa da sormena». Aldiz, jakin badakigu gure emozioetan pentsatzeko moduak eragiten duen bezala, pentsamenduetan ere sentitzeko moduak eragin zuzena duela. Hortaz, ezinbestekoa da sormenean alderdi afektibo-pertsonalek duten parte hartzea ikertzea, hain konplexua den fenomenoa ulertu nahi bada.

\subsection{Emozioen eta sormenaren garrantzia psikologian}

Fenomeno emozionalen eta sormenaren arteko erlazioa azaldu aurretik, bi fenomeno hauen elkarreraginak psikologian izan duen garrantzia aztertzetik hasiko gara. Aipatu nahi dabaita emozioak eta sormenak (bakoitzak bere aldetik) psikologian izandako eboluzioa zehaztasun handiagoarekin aurkitu daitekeela Conejero, Pascual eta Etxebarriaren (2007) zein Soroa eta bere kideen (2012) ikerlanetan.

Laurogeita hamarreko hamarkadatik aurrera, emozioek eta motibazioak sormenean zuten parte-hartzea ikertzeko interesa handitzen hasi zen. Interes horren hazkundean eragina izan duten zenbait gertakizun aipatuko dira ondoren.

- Hasteko, psikoanalisiak katarsi emozional gisa ulertu izan du sormenezko prozesua. Ikuspegi horren aburuz, nahaste afektiboak dituzten pertsonek aukera gehiago dute sortzaile izateko, baita emozioz beteriko eta pasiozko pertsonek ere, zeintzuk bizipen berriak izatea gustukoa duten. Sormena ikertzen duten psikoanalistek garrantzi berezia ematen diote intuizioari edo arrazonamendurik gabeko ezagutzari (Winicott, 1993). 
- Nahiz eta duela gutxi arte eredu kognitibo-konduktistek sormenaren alderdi kognitiboari eman dioten lehentasuna, gaur egun alderdi pertsonalek, afektiboek eta sozialek sormenean duten pisua nabarmena da (Tierney eta Farmer, 2002).

- Emozioen eredu teorikoak garatzen joan diren heinean, horien inguruko ezagutza- eta ikerkuntza-metodoak hobetzen joan dira. Horri zor zaio baita sormenaren baitan alderdi emozionalak kontuan hartzen dituzten ikerketa-kopurua handitzea (Lewis, Haviland-Jones eta Barrett, 2008).

- Bestalde, emozioen eta kognizioaren neurozientziaren emaitzei esker frogatu izan da giza jokabidean parte hartzen duten dimentsio emozional eta kognitiboek elkarri eragiten diotela oinarrizko prozesu psikologikoetan; hots, ikaskuntzan, arreta eta pertzepzioan, oroimenean, adimenean eta sormenean (Damasio, 2001; Russell eta Barrett 1999).

- Psikologia sozialaren korrontetik abiatuta, testuinguru sozio-kulturalak sormenarekin izandako erlazioak areagotu eginzuen sormena ikertzeko interesa. Bestalde, Mendebaldeko gizartean emozioak modan daude nolabait, eta emozioek balio positiboa hartu dute (Fernández-Abascal, 2008). Azken hamarkadetan, populazioaren sektore askotan (gizarte aberatsetan bereziki) bizitzaren osotasuna intentsitate handiko emozioak bizitzearekin lotzen da. Emozio biziez gozatzeko desirarekin batera, haiek aztertzeko interesa ere piztu dela dirudi.

- Oinarrizko psikologiaren korrontetik, aldiz, pertsona sortzaileen baitan dauden ezaugarriekin zerikusia duten ekarpen garrantzitsuek piztu dute sormena ikertzeko interesa. Ikuspegi horren baitan daude nortasuna, motibazioa eta beste...

- Berriki, ikuspegi bateratzaile bat nagusitu da, zeinak psikologiaren arlo desberdinek sormenaren ikerketa banatu dutela kritikatzeaz gain, sormena bere osotasunean eta modu integratzailean ikertzea bultzatuko duen. Horrela, laurogeita hamarreko hamarkadan autore batzuen iritziz, prozesu sortzailea ezin da ikertu ikuspegi kognitibo batetik soilik, baizik eta elementu sozio-pertsonalak ere kontuan hartuz (Baas et al., 2008; Davis, 2009; To, Fisher, Ashkanasy eta Rowe, 2012). Gure ikerlana, ikuspegi bateratzaile horretan oinarritzen da funtsean.

- Azkenik, emozioa eta kognizioa bateragarriak eta osagarriak direla ondorioztatzen duen kontzeptua ematen du ezagutzera Daniel Goleman-ek (1995), hots, adimen emozionala. Horrek emozioen ikerkuntza bultzatzen badu ere, esan beharra dago, Salovey eta Mayer psikologo estatubatuarrek 1990. urtean kontzeptuaren definizioa aurkeztu zutenean bere eragina ez zela oso handia izan, eta ez zitzaiola garrantzi handirik eman zientziaren arloan. Haatik, azken urteotan burututako hainbat ikerketak ondorioztatzen dute funtsezkoa 
dela norberaren eta gainerakoen sentimenduak eta emozioak behar bezala ezagutzea, ulertzea eta erregulatzea, ingurura erraztasun eta eraginkortasun handiagoarekin egokitu ahal izateko (Goleman, Boyatzis eta McKee, 2013).

Gaur egun, gaitasun tekniko eta arrazionaletan oinarritutako eredu teorikoak aldatzen ari dira eta nabarmentzen hasi dira emozioak kontuan hartzen dituzten ereduak (Barsade eta Gibson, 2007; Repetto, 2003). Batetik arrakasta profesionala, indibiduala eta soziala, eta, bestetik, osasun fisikoa eta mentala, neurri handi batean gaitasun sozioemozionalen araberakoa direla esaten da. Horri lotuta, norbanakoa hezkuntza emozionala eta sormena ezinbestekoak dira hezkuntza-, erakunde- eta gizarte-arloetan (Pekrun eta Linnenbrink-Garcia, 2014).

Jarraian, emozioen eta sormenaren arteko erlazioa ulertzen saiatuko gara.

\subsection{Fenomeno emozionalen eta sormenaren arteko denborazko erlazioak}

Bi fenomeno horien arteko denborazko erlazioa aztertzerakoan, gerta daiteke biak aldi berean gertatzea, edo fenomeno emozionalak sormenaren aurretik nahiz atzetik joatea. Erlazio mota bakoitzean aurkitutako emaitza adierazgarrienak laburki aztertuko dira ondoren.

- Fenomeno emozionalak sormenaren aurrekari gisa. Hiruetatik gehien ikertu izan den lerroa da hau, besteak beste, emozioek sormenean betetzen dituzten funtzioek duten garrantziagatik (adib. Baas, De Dreu eta Nijstad, 2008). Lehenik, emozioek errealitatearen informazio-iturri gisa jokatzen dute, norberak esanahi subjektiboa jakin batez janzten du errealitate horri eta, hortaz, originaltasuna zein indibidualtasuna egozten dizkio bere bizipenari. Bigarrenik, emozioak sormenezko prozesuan zehar erabakiak hartzeko eta eginkizun berriei ekiteko energia-iturri garrantzitsuak dira. Hirugarrenik, hausnarketa logikoa eta arrazionala egin aurreko intuizioa eskaintzen dute emozioek, bizipenak norberaren balore eta oroimen emozionalen bitartez aberastuz. Horrela, topatutako ideia berri guztien artean egokiena aukeratzeko prozesua arindu egiten da. Azkenik, inkubazioari esker (Wallas-en sormenezko prozesuaren 3. fasea) afektu positiboa dugun egun batean pentsamenduaren jariakortasuna hobetzen bada, hurrengo egunean ere ideia sortzaileak izateko aukera mantenduko da (hurrengo lau gauetaraino luzatu daitekeelarik).

- Fenomeno emozionalak sormenaren ondorio gisa. Oro har, sormenezko zeregin batek arrakasta edo porrota dakarrenean, erreakzio emozionalak eragiten ditu segidan (Frijda eta Mesquita, 1994; 
Oatley, Keltner eta Jenkins, 2006; Russell eta Barrett, 1999). Ikertzaile ugarik frogatu du erronka bati modu sortzailean aurre egiteak edo arazo bati irtenbide berritzaile bezain eraginkorra emateak, gogo-aldarte positiboa eragiten duela, eta sarri euforia-sentimenduak sortzen dituela (Akbari Chermahini eta Hommel, 2012; Feist, 2014; Wilson, Cenberbar, Kramer eta Gilbert, 2005). Aldiz, proposatutako helburua nahi bezala ez betetzeak eragin ezkorrak izan ditzake afektuan, norberak bere buruaz duen irudikapenean eta zereginari eusteko motibazioan.

- Fenomeno emozionalen eta sormenaren aldiberekotasuna. Sentitutako emozioak hertsiki lotzen dira sormenarekin; izan ere, aldi berean sentitu eta sortu daiteke, bi ekintzak koordinatu eta elkarri eragiten diotelarik. Pentsamendu sortzailea eskatzen duen zeregin batek pertsonaren gogo-aldartean eragiten duen bezala, pertsonaren emozioek ere eragin dezakete sormenean (Bar, 2009; Salovey, Mayer eta Caruso, 2002). Csikszentmihalyi-k (1990) iradoki zuen portaera sortzaileak bereizgarri duela pertsonaren eta ekintzaren arteko lotura psikologikoa, zeinak plazera eta gogo bizia bezalako sentimendu positiboak barne hartzen dituen. Kontzeptualki, ekintza sortzaile baten aurrean sentitzen ditugun emozioek barne-motibazioaren antzeko ezaugarriak dituzte (Amabile, Barsade, Mueller eta Staw, 2005).

Ikerkuntza zientifikoaren arabera, aipatu berri diren hiru erlazio mota hauek ez dute zertan baztertzaileak izan behar, guztiak eta hauetako bakoitza gertatu baitaiteke. Hau da, fenomeno emozionalek sormenezko prozesuaren hasieran, amaieran eta fase ezberdinetan agertu daitezke, bi fenomenoen artean lerro izaerako erlazioa eratuz (Zenasni eta Lubart, 2008).

\subsection{Fenomeno emozionalen balentzia eta sormena}

Jarraian fenomeno emozional positiboek zein negatiboek sormenean izan dezaketen eragina erakutsiko da. Baita aldakortasun afektiboaren (emozio batetik bestera pasatzea) ondorioak ere.

\section{Fenomeno emozional positiboak eta sormena}

Aditu askok iradoki du sormenezko prozesua eraginkorragoa dela afektu positiboek parte hartzen dutenean eta erronka baten aurrean motibazio maila altua dagoenean (afektu negatiboekin eta motibazio maila baxuarekin alderatuz). Izan ere, gogo-aldarte positiboak gure ingurua antolatzen dugun moduari eragiten dio, kategorizazio-prozesuak erraztuz, kategorien arteko mugak apurtuz, euren edukia aberastuz eta antzekotasuna duten elementuen parte hartzea posible eginez (Fredrickson eta Branigan, 2005). 
Era berean, afektu positiboak malgutasun kognitiboa bultzatzen du, ideien arteko asoziazioa eragiten du eta estimulu berdin nahiz ezberdinen arteko erlazio anitzak ezartzea ahalbidetzen du, alderdi guzti horiek sormenarekin lotura zuzena dutelarik (Ivcevic, Brackett eta Mayer, 2007). Hainbat lanetan aurkitu den bezala, afektu positiboa eragiten zitzaien parte-hartzaileek afektu negatiboa jasaten zutenek baino modu originalagoan egiten zieten aurre braimstorming (ideia-zaparrada) bidezko zereginei (Gotschke, 2006).

Emozioaren eta sormenaren erlazioa aztertzen duen meta-analisi batean, Davis-ek (2009) azterketa sakonago bat egin zuen zeregin sortzaileak bitan banatuz; batetik, pentsamendu dibergentea ${ }^{2}$ eskatzen zutenak (ideiak sortzea, kategorizazioak eta urruneko asoziazioak) eta bestetik, pentsamendu konbergentea ${ }^{3}$ eskatzen zutenak (arazo-konponketa, ideien ebaluaketa eta erabakiak hartzea). Horrela, afektu positiboaren onurak soilik pentsamendu dibergentea eskatzen zuten zereginetan aurkitu zuen Davisek (pentsamendu konbergentea eskatzen zutenekin alderatuta).

\section{Fenomeno emozional negatiboak eta sormena}

Emozio negatiboek pentsamendu sortzailean duten eragina emozio positiboena baino konplexuagoa da. Batetik, hirurogeita hiru ikerlanetako emaitzak biltzen dituzten bi meta-analisitan ez da emozio negatiboen eta pentsamendu dibergentearen arteko harreman esanguratsurik topatu (Baas et al., 2008; Davis, 2009). Bestetik, beste ikerlari batzuek iradoki dute afektu negatiboek pentsamendu konbergentearen baitan dauden pentsamendu kritikoa (Rathunde, 2000) eta iraunkortasuna (De Dreu, Baas eta Nijstad, 2008) areagotzen dutela. Martinek eta Stoner-ek (2014) proposatutako gogo-aldartea input gisa deritzon ereduari jarraiki, gogo-aldarte negatiboa sentitzen duenak (positiboa sentitzen duenarekin alderatuz) arazoen aurrean konponbide original eta egoki bat topatzeko gehiago ahalegindu beharko duela pentsatuko du. Azkenik, badira emozio negatiboak pentsamendu dibergentea eskatzen duten zereginekin negatiboki erlazionatu direla aurkitu duten ikerlanak ere (esaterako, DeMoss, Milich eta DeMers, 1993).

Fenomeno emozional negatiboen eta sormenaren arteko erlazioan oinarritutako ikerketa-lerroak nahaste afektiboetan du jatorria. Izatez, sormenean goi-mailako talentua erakusten duten pertsonekin eta euren senitartekoekin burututako ikerlan ugarik zera eman dute aditzera: nahaste afektiboak (batez ere nahaste bipolarra eta depresioa) sufritzen dituzten pertsona gehiago aurkitzen direla sortzaileen artean, populazio orokorrare-

\footnotetext{
2 Pentsamendu dibergentea edo albokoa: arazo bat konpontzeko asmoz, aukera ugari, ezberdina eta berriak biltzea da (adib.: gai askeko marrazki bat egitea edo ideia-zaparrada).

${ }^{3}$ Pentsamendu konbergentea: arazo bat konpontzeko asmoz, erantzun bakar, egoki eta zuzena bilatzea da (adib.: test moduko azterketa bat).
} 
kin alderatuz (Feist eta Barron, 2003). Erlazio hori bereziki sormen artistikoaren testuinguruan aurkitu da, baina ez beste testuinguruetan (adib. zientifikoan).

\section{Aldakortasun afektiboa eta sormena}

Jamison-en (1995) aburuz, aldakortasun afektiboak (hots, emozio positiboetatik negatiboetara pasatzea edo alderantziz) sormena hobetzen du, itxuraz kontraesanezkoak diren emozio-konbinazioak bizitzen direlako. Aditu honek iradokitzen du afektuan izandako aldaketak sormenerako garrantzitsuagoak izan daitezkeela, afektu estatikoekin konparatuz, eta bereziki, emozio negatiboetatik emozio positiboetara aldatzea.

Nahaste bipolarraren diagnostikoa zuten pertsonekin burututako ikerketa batean zera aurkitu zuten Shaw-k eta bere kideek (1986): litioak umorearen aldakortasuna deuseztatzen zuen heinean, zeharkako moduan behinik behin, gaixo horien sormenezko emankortasuna gutxitu egiten zela. Izan ere, aldakortasun afektiboaren baitan daude pertsona horiek behar duten inspirazioa eta sormenerako aktibazioa. Nahaste bipolarra dutenen mania-faseetan ohikoa da euforia sentitzea, aktibitatea eta asaldadura areagotzea, lo egiteko beharra gutxitzea, ekintza berrietan murgildu nahi izatea eta pentsamendu dibergentea hobetzea (Gruber, Mauss, Tamir, 2011). Aldiz, mania faseetan haserrea sentitu ohi da eta ebaluaziorako gaitasunak gutxitu; beraz, sortutako ideien artean bakarra hautatzeko prozesua kaltetu egiten da (Srivastava eta Ketter, 2010). Ondorio horiek ezagutzera ematen dute emozio positiboak aktibazio-maila oso altuarekin sentitzen direnean (adib., mania-faseetan ohikoa den euforia) ideien jariakortasuna, malgutasuna eta originaltasuna areagotzen direla; aldiz, ideien kalitatea gutxitu egiten dela eta akats kopurua handitu (Kaufmann eta Kaufmann, 2014).

Ikusi berri ditugun emaitzek aditzera eman dute, modu batera edo bestera, emozio positiboek eragina dutela pentsamendu dibergentea eskatzen duten zereginetan; negatiboek, aldiz, pentsamendu konbergentea eskatzen dutenetan. Gainera, gaixotasun bipolarraren inguruan aurkitutako emaitzek ikerketa-lerro berria irekitzen dute afektuaren balentziak (positiboa edo negatiboa) sormenean izan dezakeen eraginean (indartzailea ala inhibitzailea) aktibazio-mailak duen paperaren inguruan. Hortaz, literatura zientifikoan eztabaida honek jasotako emaitzak eta ekarpenak aztertuko dira ondoren.

\subsection{Aktibazio-maila, erregulazio-fokua eta sormena}

Hainbat ikerlanek azpimarratzen dute afektuak sormenean izan dezakeen eragina ezin dela soilik balentziaren bitartez ulertu, aktibazio-maila 
ere kontuan hartu behar dela ezinbestean (Fredrickson, Cohn, Coffey, Pek eta Finkel, 2008). Labur bada ere, komeni da hemen aipatzea Russell-ek (1980) bi dimentsio bereizten dituela esperientzia emozional guztiak sailkatzeko: aktibazio-maila (altua edo baxua) eta balentzia mota (atsegina edo desatsegina). Horrela, emozioak zirkulu bateko guneetan kokatuko lirateke euren aktibazio eta plazer mailaren arabera. Eredu honi «eredu zirkularra» deitu zion Russellek. Ikus 1. irudia.

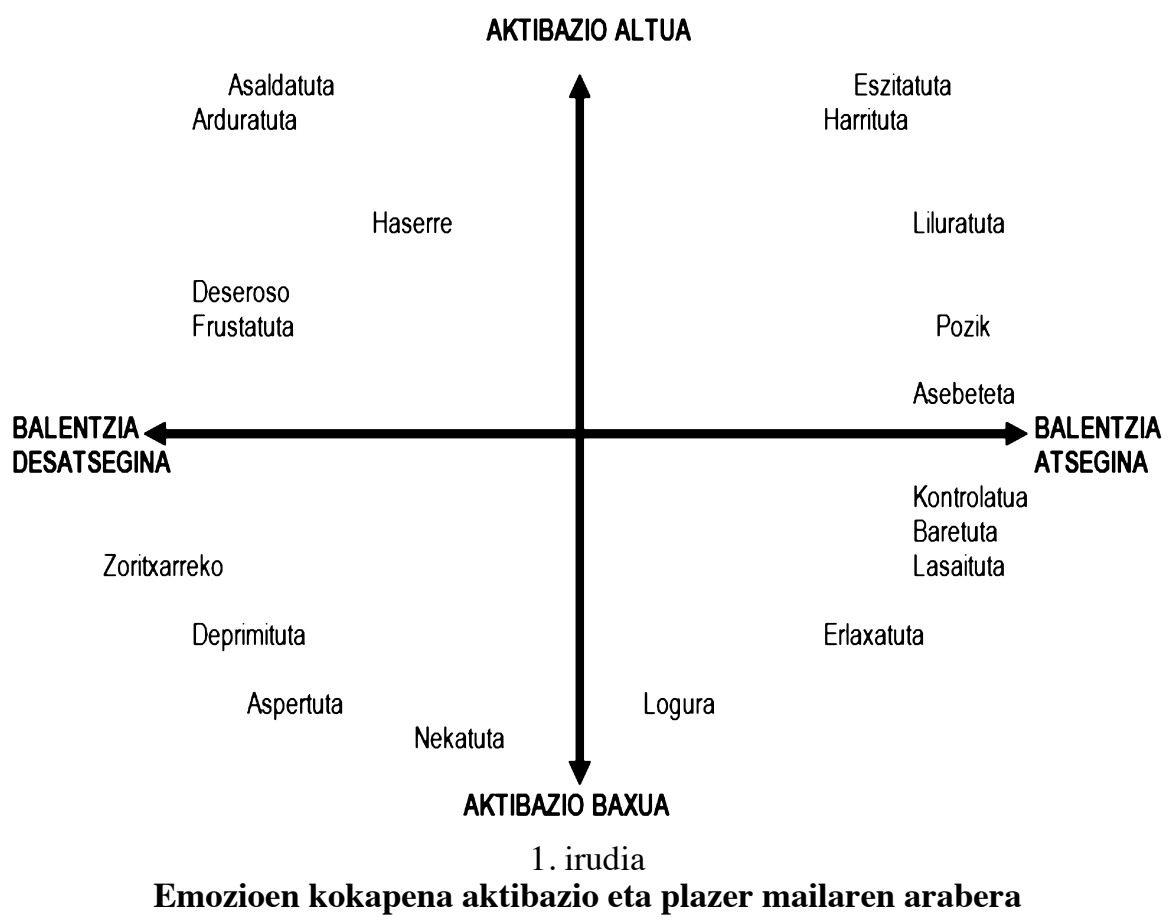

Berriagoa den beste ikerlan batean, Sormenaren bide bikoitzaren eredua (The Dual Pathway Model; De Dreu et al., 2008) proposatu zuten afektuaren balentzia eta aktibazio-maila kontuan izanez. Ikerlan horretatik eratorritako emaitza batzuk aurkezten dira jarraian.

\section{Aktibazio-maila eta sormena}

Aktibazio-maila erreakzio fisiologikoen, kognitiboen eta afektiboen arteko emaitza da (Bradley, 2000; Gailliot et al., 2007; Russell eta Barrett, 1999). Pertsona bat zeregin baten aurrean aktibatuta (alai, grinatsu, baikor, haserre, frustratuta, etab.) edo aktibazio-maila baxuarekin (lasai, erla- 
xatuta, bare, etab.) egon daiteke; besteak beste, zereginak eragiten dizkion sentsazio, pentsamendu eta sentimenduen arabera.

Hainbat adituren arabera, aktibazio-maila ertaineko emozioek sormena areagotzen dute muturreko aktibazio-mailekin (baxuegia edo altuegia) alderatuz. Besteak beste: 1) Arazoak modu sortzaileagoan konpontzeko motibazioa areagotzen da; 2) Dopamina eta noradrenalinaren mailak igotzean, oroimenak hobera egiten du, batez ere epe luzekoak; 3) Prozesu kognitiboak oro har malguagoak bilakatzen dira; 4) Pentsamendu abstraktua eta metaforikoa hobetu egiten da; eta 5) Informazioa prozesatzeko abiadura azkartu egiten da (Baas et al., 2011; Byron, Khazanchi eta Nazarian, 2010; Colzato, Kool eta Hommel, 2008; Gilet eta Jallais, 2011).

\section{Erregulazio-fokua eta sormena}

Erregulazio-fokuak eta prozesu afektiboek pertsonen gaitasun sortzailearekin erlazionatzen diren moduak hainbat adituren interesa piztu du (Förster eta Dannenberg, 2010; Herman eta Reiter-Palmon, 2011; Molden eta Hui, 2011).

Pertsonek funtsezko bi erregulazio-fokuren arabera kudeatzen dituzte euren helburuak, emozioak eta portaerak : promoziozkoa eta prebentziozkoa (Higgins, 2002). Promoziozko fokuaren bitartez, pertsonek aukera berriak, erronkak eta lortu gabeko zereginak betetzera bideratzen dituzte euren esfortzuak, gogo-aldarte positiboa mantendu edo lortu ahal izateko. Motibazio mota hau alaitasunarekin erlazionatzen da, helburuen lortzea gertu dagoenean edo burutu denean; aldiz, haserrearekin eta frustrazioarekin erlazionatzen da helburuak lortzeko zailtasunak daudenean, eta tristurarekin desiratutako helburua ezin izan denean lortu. Prebentziozko fokuaren bitartez motibatutako pertsonek zailtasunak eta porrotei lotutako gogo-aldarte negatiboak ekiditera bideratzen dituzte euren ahaleginak ziurtasuna eta erantzukizuna mantendu ahal izateko. Bigarren erregulazio mota hau lasaitasunarekin lotutako emozioekin erlazionatzen da helburuak lortzen direnean; aldiz, beldurra, kezka eta tentsioarekin helburuak ez direnean lortzen (adib. Molden, Lee eta Higgins, 2008).

\section{Aktibazio-maila, erregulazio-fokua eta sormena}

Azken hamarkadan sormena eta fenomeno emozionalaren arteko erlazioa ikertu dutenen artean nabarmena izan da aktibazio-maila eta sormena erregulatzeko fokua konbinatzeko interesa (adib. Baas et al., 2008; Carver, 2004; Fredrickson eta Branigan, 2005). Jarraian laburbiltzen dira ikerketalerro honetatik abiatuta lortutako ondorio garrantzitsuenak:

- Aktibaturiko gogo-aldarteak promoziozko motibazioaren baitan daudenean (adib. alaitasuna edo haserrea), sormena areagotu eta es- 
timulatu egiten da; ideien originaltasuna, malgutasuna eta jariakortasuna hobetu egiten da, eta arreta fokua xehetasunetatik ikuspegi orokorrago batera zabaldu.

- Aktibaturiko gogo-aldarteak prebentziozko motibazioaren baitan daudenean (adib. beldurra edo urduritasuna) sormena areagotu eta estimulatu egiten da, baldin eta lortu nahi den helburua oraindik bete gabe badago. Aldiz, helburua beteta edo bideratuta egoteak dakarren desaktibazioak (adib. lasaitasuna) sormena eragotziko luke: ideien originaltasuna, malgutasuna eta jariakortasuna mugatu egingo lirateke eta kontzeptuen arteko distantziak murriztu.

- Aktibatu gabeko gogo-aldarteak, - promoziozko (adib. tristura) nahiz prebentziozko (adib. erlaxazioa) motibazioaren baitakoak diren inporta gabe - , ez dira sormenarekin erlazionatzen.

Funtsean, aktibazio-maila ertaina dela sormena areagotu edo eragozten duen aldagai nagusia ondorioztatu daiteke, erregulazio-fokua modu batekoa edo bestekoa izanda ere.

\section{FENOMENO EMOZIONALAK ETA SORMENA UZTARTZEN DITUZTEN EREDU TEORIKOAK}

Puntu honetan aurkezten diren eredu teorikoek, neurri handiagoan edo txikiagoan, emozioen eta sormenaren arteko erlazioa hobeto ulertzen lagunduko dute. Hasteko, azken 25 urteotan sormena aztertzen saiatu diren ikerlanak zerrendatuko dira (ikus 1. taula). Ikerlan horietan, sormenaren ohiko lanetan ez bezala, aintzat hartzen dira nortasun ezaugarriak, motibazioa, emozioak eta gaitasun sozioemozionalak.

Ondoren, taulan agertzen diren ereduetariko lau deskribatuko dira Hezkuntza arloan izan dezaketen interesagatik edo/eta aplikagarritasunagatik. Hain zuzen, lehenengo ereduak emozio sortzaileen inguruko ikerketa-lerro berri bat irekitzen du, zeinak pertsonek emozio berriak, eraginkorrak eta berezkoak adierazteko gai izan daitezkeela iradokitzen digun (Averill, 1999). Bigarren ereduak sormenaren baitan dauden alderdiak ezagutarazten ditu, besteak beste, alderdi pertsonal eta afektiboak azpimarratuz (Alfonso, 2000). Hirugarren ereduak adimen emozionala eta gaitasun sortzaileak uztartzearen aplikagarritasuna erakusten digu (Zhou eta George, 2003). Azken ereduak emozioen eta sormenaren arteko elkarreragina norabide anitzekoa izateaz gain (aldi berean, emozioak sormenaren ondorio edo aurrekari izanik), emozioen balentziaren eta testuinguruaren eraginaren araberakoa izan daitekeela azalduko digu (Amabile et al., 2005). 


\section{Emozioak eta sormena uztartzen dituzten ereduak}

\begin{tabular}{|c|c|c|c|}
\hline Urtea & Autoreak & Eredu teorikoa & Ikertutako alderdiak \\
\hline 1991 & $\begin{array}{l}\text { Sternberg eta } \\
\text { Lubart }\end{array}$ & $\begin{array}{l}\text { «Sormenaren inber- } \\
\text { tsioaren eredua» }\end{array}$ & $\begin{array}{l}\text { Gaitasun intelektualak, ezagutza, } \\
\text { pentsamendu estiloak, nortasuna, mo- } \\
\text { tibazioa eta testuingurua }\end{array}$ \\
\hline 1997 & Bar-On & $\begin{array}{l}\text { «Adimen emozionala- } \\
\text { ren eredu mistoa» }\end{array}$ & $\begin{array}{l}\text { Pertsonaren baitan dagoen Kozien- } \\
\text { te Emozionala }(\mathrm{KE}) \text {, pertsonen arteko } \\
\text { KE, egokitzapeneko KE, estresaren } \\
\text { erabileraren KE eta aldarte oroko- } \\
\text { rraren KE }\end{array}$ \\
\hline 1997 & $\begin{array}{l}\text { Mayer } \\
\text { eta Salovey }\end{array}$ & $\begin{array}{l}\text { «Adimen emozionala- } \\
\text { ren lau adarren eredua» }\end{array}$ & $\begin{array}{l}\text { Emozioei arreta jartzea eta per- } \\
\text { tzepzioa, emozioen ulermena, emo- } \\
\text { zioek pentsamendua erraztea eta } \\
\text { emozioen erregulazioa }\end{array}$ \\
\hline 1998 & Getz eta Lubart & $\begin{array}{l}\text { «Sormenean emozioek } \\
\text { duten erresonantziaren } \\
\text { eredua» }\end{array}$ & Emozioak, sormena eta oroimena \\
\hline 1999 & $\begin{array}{l}\text { Ashby, Isen eta } \\
\text { Turken }\end{array}$ & $\begin{array}{l}\text { «Kognizioan afektu po- } \\
\text { sitiboek duten eraginaren } \\
\text { eredu neuropsikologikoa» }\end{array}$ & $\begin{array}{l}\text { Afektu positiboak eta prozesu kog- } \\
\text { nitiboak }\end{array}$ \\
\hline 1999 & Averill & $\begin{array}{l}\text { «Emozio sortzaileen } \\
\text { eredua» }\end{array}$ & $\begin{array}{l}\text { Emozioekiko joera, berritasuna, } \\
\text { eraginkortasuna eta berezkotasuna }\end{array}$ \\
\hline 1999 & Russ & $\begin{array}{l}\text { «Sormenaren proze- } \\
\text { su afektiboen eta kogniti- } \\
\text { boen eredua» }\end{array}$ & $\begin{array}{l}\text { Nortasun sortzailearen ezauga- } \\
\text { rriak, sormenaren prozesu afektiboak } \\
\text { eta kognitiboak }\end{array}$ \\
\hline 2000 & Alfonso & $\begin{array}{l}\text { «Sormenaren alderdi } \\
\text { kognitiboen eta afektibo- } \\
\text { pertsonalen eredu batera- } \\
\text { tzailea» }\end{array}$ & $\begin{array}{l}\text { Norberaren oinarrizko ezagutzak, } \\
\text { gaitasun kognitiboak, jarrerak, norta- } \\
\text { suna eta emozioak }\end{array}$ \\
\hline 2002 & $\begin{array}{l}\text { Goleman, } \\
\text { Boyatzis } \\
\text { eta McKee }\end{array}$ & $\begin{array}{l}\text { «Lidergo emozionala- } \\
\text { ren eredua» }\end{array}$ & $\begin{array}{l}\text { Auto-ezagutza, auto-erregulazioa, } \\
\text { motibazioa, enpatia eta gaitasun so- } \\
\text { zialak }\end{array}$ \\
\hline 2003 & Zhou eta George & $\begin{array}{l}\text { «Sormena aktibatzen } \\
\text { duen Adimen Emoziona- } \\
\text { laren eredua» }\end{array}$ & $\begin{array}{l}\text { Adimen emozionalaren trebetasu- } \\
\text { nak eta sormenezko prozesuaren fa- } \\
\text { seak }\end{array}$ \\
\hline 2005 & $\begin{array}{l}\text { Fredrickson eta } \\
\text { Branigan }\end{array}$ & $\begin{array}{l}\text { Emozioen eta estrate- } \\
\text { gia kognitiboen arteko er- } \\
\text { lazioa }\end{array}$ & $\begin{array}{l}\text { Arreta zabaltzea, baliabide kogni- } \\
\text { tiboak areagotzea eta ekintzak mar- } \\
\text { txan jartzea }\end{array}$ \\
\hline
\end{tabular}




\begin{tabular}{|c|c|c|c|}
\hline Urtea & Autoreak & Eredu teorikoa & Ikertutako alderdiak \\
\hline 2005 & $\begin{array}{l}\text { Amabile, } \\
\text { Barsade, Mueller } \\
\quad \text { eta Staw }\end{array}$ & $\begin{array}{l}\text { «Afektuen eta sormena- } \\
\text { ren zikloaren eredua» }\end{array}$ & $\begin{array}{l}\text { Emozioak, sormena, prozesu kog- } \\
\text { nitiboak eta testuingurua }\end{array}$ \\
\hline 2007 & $\begin{array}{l}\text { Ivcevic, Brackett } \\
\text { eta Mayer }\end{array}$ & $\begin{array}{l}\text { Adimen emozionala eta } \\
\text { sormen emozionalaren ar- } \\
\text { teko erlazioa }\end{array}$ & $\begin{array}{l}\text { Emozioak, adimena, sormena, adi- } \\
\text { men emozionala eta sormen emo- } \\
\text { zionala }\end{array}$ \\
\hline 2006 & $\begin{array}{l}\text { Russ } \\
\text { eta Schaefer }\end{array}$ & $\begin{array}{l}\text { «Emozioaren eskema } \\
\text { hirukoitza» }\end{array}$ & $\begin{array}{l}\text { Emozioetan pentsatzea, gogo-al- } \\
\text { dartea ezagutzeari irekia egotea, } \\
\text { erronkekiko plazera sentitzea, ara- } \\
\text { zoak konpontzeko motibazioa iza- } \\
\text { tea, arrazonamendua emozioen par- } \\
\text { te egitea }\end{array}$ \\
\hline 2008 & $\begin{array}{l}\text { De Dreu, Baas } \\
\text { eta Nijstad }\end{array}$ & $\begin{array}{l}\text { «Sormenaren bide bi- } \\
\text { koitzaren eredua» }\end{array}$ & $\begin{array}{l}\text { Emozioen balentzia, aktibazio- } \\
\text { maila eta sormena }\end{array}$ \\
\hline 2009 & Davis & $\begin{array}{l}\text { Sormenean gogo-aldar- } \\
\text { teak duen eragina }\end{array}$ & $\begin{array}{l}\text { Fenomeno emozionalak eta sor- } \\
\text { mena }\end{array}$ \\
\hline 2011 & Kurman eta Hui & $\begin{array}{l}\text { Sormenean aktibazioak } \\
\text { eta motibazioak duen era- } \\
\text { gina }\end{array}$ & $\begin{array}{l}\text { Emozioen aktibazio-maila, moti- } \\
\text { bazio mota eta sormena }\end{array}$ \\
\hline 2012 & $\begin{array}{l}\text { To, Fisher, } \\
\text { Ashkanasy eta } \\
\text { Rowe }\end{array}$ & $\begin{array}{l}\text { Emozioen eta sormena- } \\
\text { ren erlazioa pertsonartean }\end{array}$ & $\begin{array}{l}\text { Emozioen balentzia, aktibazio- } \\
\text { maila, sormena, motibazioa eta ba- } \\
\text { besa }\end{array}$ \\
\hline 2013 & $\begin{array}{l}\text { Baas, Roskes, } \\
\text { Sligte, Nijstad } \\
\text { eta De Dreu }\end{array}$ & $\begin{array}{l}\text { Sormenaren bide bikoi- } \\
\text { tzaren eredua eta norta- } \\
\text { suna }\end{array}$ & $\begin{array}{l}\text { Emozioen balentzia, aktibazio- } \\
\text { maila, sormena eta nortasun ezau- } \\
\text { garriak }\end{array}$ \\
\hline
\end{tabular}

Taulan grisez nabarmendu diren ikerlanak izango dira hurrengo puntuetan deskribatuko direnak. Beste edozein ikerlanean sakontzeko interesa duen irakurleak jatorrizko erreferentziara jo dezake.

\subsection{Emozio sortzaileen eredua (Averill, 1999)}

James Averillek (1999) honela definitzen ditu emozio sortzaileak: «Emozioak modu sortzailean, berritzailean eta eraginkorrean ulertzeko eta adierazteko berezko gaitasuna». Definizio honetan lau alderdi bereizi daitezke, zeintzuk hurrengo irudian (2. irudia) erakusten diren: 


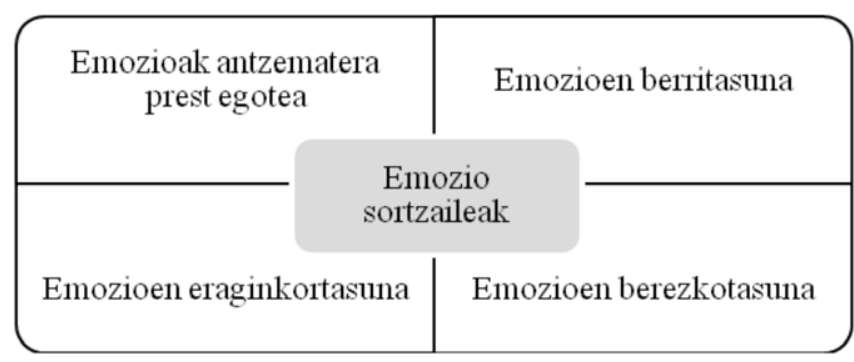

2. irudia
Averillen emozio sortzaileen eredua (1999)

- Emozioekiko joera. Norberaren eta gainerakoen emozioei arreta jartzeko nahia litzateke, emozio hauek ulertu ahal izateko eta alderdi emozionala intelektuala bezainbeste garatu ahal izateko. Alderdi honen eta ereduaren beste hiruen arteko erlazioa estua da; izan ere, emozioak antzemateko prest dagoen edonork erraztasun handiagoa izango du (prest ez dagoenarekin alderatuz) arazo bat konpontzerakoan irtenbide berritzaile bezain eraginkorra lortzeko, eta, bide batez, pertsonaren nortasunarekin bat datorren irtenbidera iristeko (berezkotasuna).

- Berritasuna. Pertsona jakin batek emozio berriak eta ez ohikoak sentitu eta adieraztea litzateke. Litekeena da baita emozionalki sortzailea den pertsonak emozio ezberdinen konbinazioa sentitzea.

- Eraginkortasuna. Pertsona jakin batek sentitzen dituen emozioak errealitatearekin bat datozela eta norberarentzat edota taldearentzat onuragarriak direla adierazten du alderdi honek. Kontuan hartu behar da eraginkortasuna kontzeptu erlatiboa dela, izan ere, testuinguru batean eraginkorra den emozio batek, ez du zertan beste testuinguru batean ere izan.

- Berezkotasuna. Pertsona jakin batek sentitzen duen emozioaren bitartez, berezkoak dituen baloreak eta bizipenak adierazten ditu modu zintzoan. Berezkotasunak ohitura sozialen eta besteek uste dutenaren aurka joatea suposatzen du sarritan. Ez da harritzekoa, beraz, kanpoko arauen aurka joaten garenean berezkoagoak izatea, eta, zentzu horretan, sortzaileago.

Averillek sormenaren adierazpen edo produktutzat hartu ditu emozioak. Horrela, pertsona emozionalki sortzaileak gai lirateke emozio berriak (originaltasuna) eta eraginkorrak (erabilgarritasuna) sortu edo sentitzeko. Dimentsio horiei prozesuaren parte den gaitasun emozional bat erantsi die, hots, emozioekiko joera. Eredu honetan oinarrituta, Searen neurketa tresna bat sortu da (ECI, Emotional Creativity Inventory; Averill 
eta Thomas-Knowles, 1991), zeinak gaztelaniazko (ECI-S; Soroa, Gorostiaga, Aritzeta eta Balluerka, prentsan) eta euskarazko (Soroa, Balluerka, Aritzeta eta Gorostiaga, 2012) bertsioak dituen.

\subsection{Sormenaren alderdi kognitiboen eta afektibo-pertsonalen eredu bateratzailea (Alfonso, 2000)}

Eredu hau beste hiru ereduren konbinaketa bat da: Amabilerena (1983), Feldhusenena (1995) eta Sternberg eta Lubartena (1991).

Alfonsok (2000) proposatutako ereduan hiru alderdi hauen arteko elementu bateragarriak azpimarratzen dira: 1) Pertsonak dituen oinarrizko ezagutzak; 2) Gaitasun kognitiboak; eta 3) Alderdi afektibo-pertsonalak. Jarraian azaltzen den irudian (3. irudia) eredu hau aurkezten da eta barne hartzen dituen alderdiak aipatzen dira.

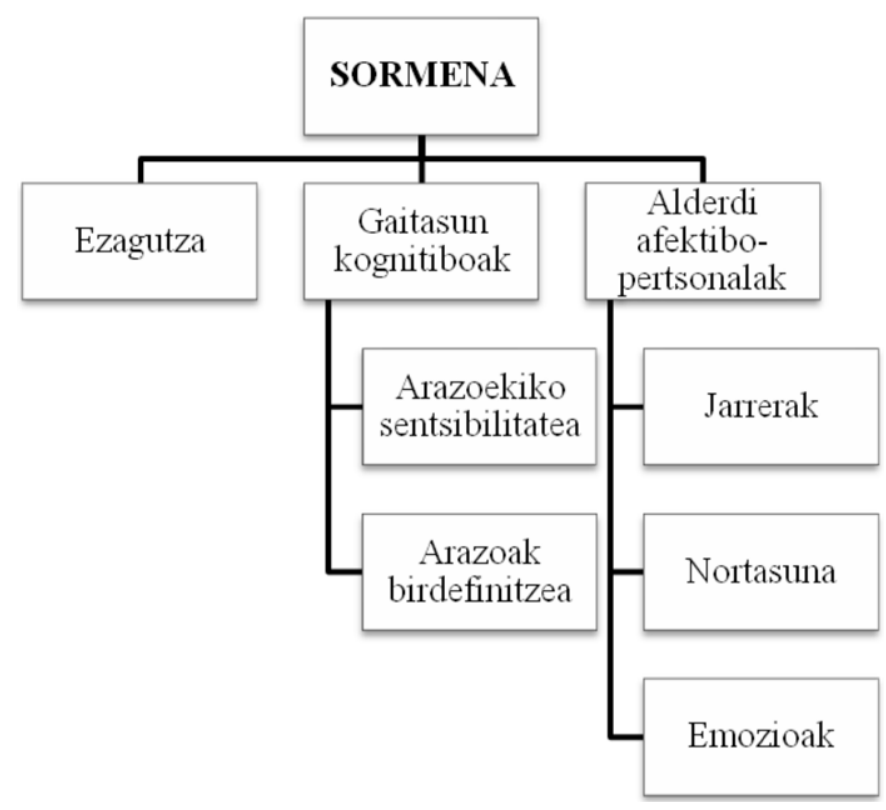

3. irudia

Sormenaren alderdi kognitiboen eta afektibo-pertsonalen eredu bateratzailea. Alfonsotik (2000) egokitua

Jarraian alderdi bakoitza deskribatzen da labur:

- Ezagutza. Sormenezko prozesuren bat hasi aurretik eta prozesuak iraun bitartean, funtsezkoa da zereginari dagokion domeinuaren in- 
guruko ezagutzak edukitzea. Izan ere, ideia ezberdinak euren artean erlazionatu ahal izatea eta kanpotik jasotako informazioa aurreko ezagutzekin konbinatzea funtsezkoa da pentsamendu sortzailea edukitzeko. Hortaz, zenbat eta ezagutza maila altuagoa izan domeinu zehatz batean, orduan eta trebetasun handiagoa izango du pertsonak konponbidea aurkitzeko eta sormenezko prozesuari amaiera emateko.

- Gaitasun kognitiboak. Gaitasun kognitiboak behar dira arazoak modu sortzailean konpondu ahal izateko. Eredu honetan honako gaitasun kognitiboak aztertzen dira: 1) Modu sortzailean pentsatzen jakitea, 2) Zentzumenetatik eratorritako informazioa modu sortzailean erabiltzen jakitea, 3) Blokeoak modu sortzailean gainditu ahal izatea, eta 4) ikuspegi berriak topatzeko gaitasuna izatea.

- Alderdi afektibo-pertsonalak. Sormena aztertzerakoan, gaitasun kognitiboez gain, pertsona batek sormenarekiko erakusten duen jarrera, nortasun sortzailearen ezaugarriak eta emozioak izan behar dira kontuan. Hauek dira aztertzen diren gaitasunak: 1) Emozioen adierazpena, 2) Kanpoko presioekiko independentea den emozionaltasuna, eta 3) Auto-kontzientzia emozionala.

\subsection{Sormena aktibatzen duen adimen emozionalaren eredua (Zhou eta George, 2003)}

Zhou eta George adituek (2003) eredu praktiko bat proposatu dute ebidentzia enpiriko handiko bi eredu uztartuz. Hain zuzen ere, sormenaren funtsezko bost faseak (Amabile, 1996) eta Adimen Emozionalaren (AE) lau trebetasun ikertuenak uztartu dituzte (Mayer eta Salovey, 1997). Aditu hauen arabera, «gaitasun sortzaileak afektuaren menpe daudenez, funtsezkoa da sormenezko prozesuan zehar sortzen diren emozioak hauteman, ulertu eta kudeatzen jakitea». Segidan laburbiltzen dira sormenezko prozesuaren baitan gaitasun emozionalak beharrezkotzat hartzen dituzten bost faseak:

1. Adimen emozionalaz baliatuz arazoak edo erronkak antzematea. Konpondu gabeko arazo edo landu gabeko erronka bat antzemateko gaitasunean datza. Horretarako, emozio negatiboek arazoak antzematen lagun dezakete (antzemate prebentiboa); aldiz, emozio positiboek erronkak proposatzen lagundu dezakete (antzemate proaktiboa).

2. Adimen emozionalaz baliatuz informazioa bilatzea eta antolatzea. Behin arazoa edo erronka antzeman denean, hurrengo urratsa informazioa bilatzea eta antolatzea da. Informazioa lortu ahal izateko garrantzitsua da norberaren emozioak ezagutzea eta gertakizunen 
arabera maneiatzea. Esaterako, esku artean informazio gehiegi izateak haserrea (kudeatzen ez jakiteagatik) edo poza (azkar topatzeagatik) eragin dezake, eta horrek zeregina azkarregi amaitutzat ematea.

3. Adimen emozionalaz baliatuz ideia berriak sortzea. Hirugarren fase honetan sormena lantzeko teknikak erabili ohi dira, bilatutako informazio guztia baliatuz, arazoa edo erronka konpontzeari bideratutako ahalik eta ideia gehien proposatzeko (ohikoak nahiz berritzaileak). Garrantzitsua da emozioak ezagutzea eta behar bezala maneiatzea, sarritan umore aldaketak gertatu baitaitezke, hots, urduritasuna, nekea, frustrazioa, amorrua, etsipena eta beste.

4. Adimen emozionalaz baliatuz ideia berriak ebaluatu eta aldatzea. Norberak proposatutako ideien artean hautaketa bat egiten da, eta jarraian, hautatutako ideia horiek besteei aurkezten zaizkie beraien iritzia jasotzeko. Fase honetan garrantzitsua da norberaren (ideia aurkeztu duenaren) eta gainerakoen (ideia ebaluatzen dutenen) emozioak ezagutu eta maneiatzen jakitea, besteen kritikak mehatxutzat hartu ordez, modu aberasgarritzat ikusteko eta guztien artean ahalik eta irtenbide original eta erabilgarriena topatzeko.

5. Adimen emozionalaz baliatuz irtenbideak martxan jartzea. Azken fase honetan, martxan jartzen dira hautatutako eta landutako irtenbideak. Hortaz, honako trebetasun emozional hauek hartu behar dira kontuan: 1) Hautatutako ideia onartua ez izateak eragin dezakeen amorrua eta etsipena hautematen jakitea, eta emozio hauen arrazoiak ulertzeko eta maneiatzeko gai izatea, zereginarekin aurrera jarraitu ahal izateko; 2) Hautatutako ideia onartua izateak eragin dezakeen gehiegizko poztasuna maneiatzea, hots, sormenezko prozesuan zehar proposatutako beste ideiekiko malgutasuna mantentzeko gai izatea.

Eredu honek ateak zabaltzen dizkio erakunde nahiz hezkuntza arloetarako baliagarriak izan daitezkeen ekimen-programak edo neurketa-tresnak garatzeari.

\subsection{Afektuen eta sormenaren zikloaren eredua (Amabile et al., 2005)}

Eredu honek emozioen eta sormenaren arteko elkarreragina norabide anitzekoa (aldi berean, emozioak ondorio edo aurrekari gisa) dela defendatzeaz gain, testuinguruaren eragina hartzen du kontuan. Amabilek eta bere kideek (2005) afektuaren eta sormenaren arteko elkarreragina ziklikoa dela adierazten dute, non edozein puntutan gerta daitekeen edozerk eragina izan dezakeen pertsonaren afektuen edota gaitasun sortzaileen gainean. Eredu honen erdigunean afektuaren eta sormenaren arteko elkarreragin zuzena gertatzen da. Batetik, ekintzarekiko pasioa sentitzeak eta erronka gainditzeak 
dakarren barne-motibazioaren maila altuak sormenean positiboki eragin dezakeela adierazten da. Bestetik, arazo bat konpontzeak zuzenean irtenbidea proposatu duenaren emozioetan positiboki eragingo duela erakusten da.

Afektuen eta sormenaren zikloan (ikus 4. irudia) agertzen diren loturen inguruko ikerketa-emaitzarik adierazgarrienak laburtuko dira jarraian:

1. Afektua-Prozesu kognitiboak: Afektu positiboa izateak errazten egiten dituzte prozesu kognitiboak eta pentsamendu dibergentea. Izan ere, arretaren fokua zabaldu egiten da eta pentsamendua malgutu, hartara ideia ezberdinen arteko loturak erraztuz.

2. Prozesu kognitiboak-Sormena: Ereduaren bigarren lotura honek inkubazioaren prozesua azpimarratzen du. Horrela, afektu positiboak sentituz pentsamendu dibergentea hobetzen bada, hurrengo egunean ere ideia sortzaileak izateko aukera mantendu egingo da.

3. Sormena-Testuinguruko gertakizunak: Norberaren ideia berri batek besteren erreakzio emozionalak eragin ditzake, funtsean, haserrea (besteren iritzien aurka badoa), tristura (espero zutena bete ez badu) edo poza (gustuko duten ideia bada).

4. Testuinguruko gertakizunak-Afektua: Lortutako emaitza sortzailearen aurrean besteen erreakzioek eragina dute norberaren afektuan. Esaterako, errefortzu positiborik ez denean jasotzen, pertsona sortzailea atsekabetuta sentitu daiteke egindako lanarekin. Aldiz, erronkaren edo arazoaren aurrean proposatutako irtenbideek besteen oniritzia jasotzen dutenean, zirkulua indartu egiten da eta afektuaren eta sormenaren elkarreragina eraginkorra izan ohi da (helburuei begira).
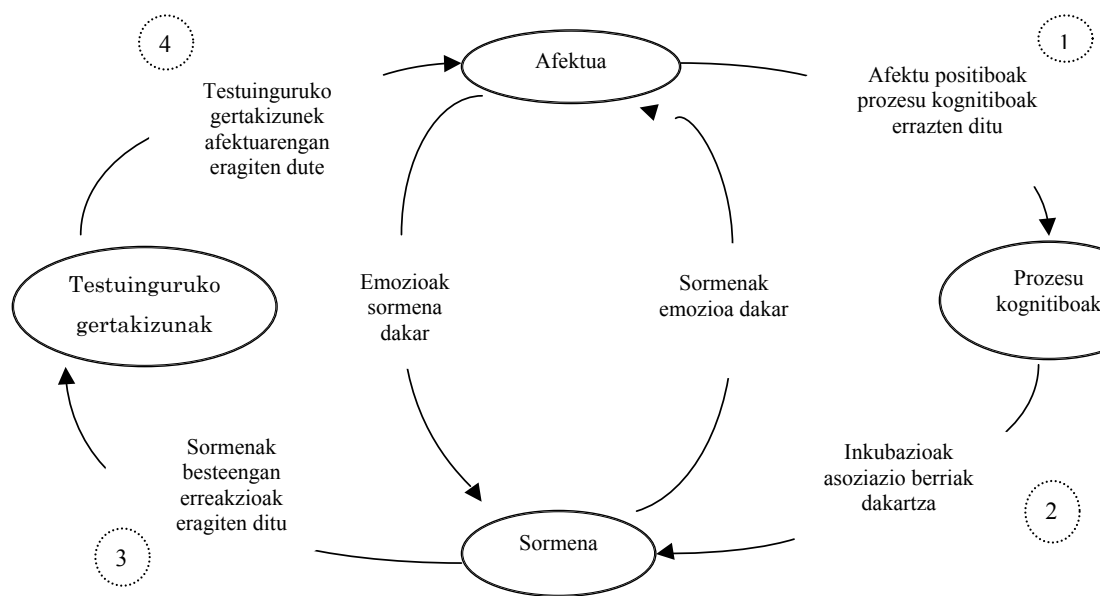

4. irudia

Afektuaren eta sormenaren zikloaren eredua

(Amabile et al., 2005: 392. or.) 


\subsection{Sormenaren bide bikoitzaren eredua (De Dreu, Baas eta Nijstad, 2008)}

De Dreu eta bere kideen (2008) eredua kontuan hartu nahi izan dugu emozioak tonuaren, aktibazio-mailaren eta erregulazio-fokuaren arabera sailkatzeaz gain, multzo bakoitzak sormenaren bi alderdiak (malgutasuna eta iraunkortasun kognitiboa) errazten dituen modua adierazten duelako.

Sormena bi modutan lortu daiteke: 1) Malgutasun kognitiboaren bitartez, zeinak kategoria kognitibo anitzak erabiltzea eskatzen duen; 2) Iraunkortasun kognitiboaren bitartez edo denboran zehar zeregin batean mantenduz. Batetik, pentsamendu malguak erlazionaturik dauden kategoria kognitibo anitzak biltzen ditu, kategoria ezberdin batetik bestera aldatzeko erraztasuna du, eta kategorien arteko loturak egiten ditu. Horrela, malgutasun kognitiboak arazo baten aurrean erantzun ugari eta originaletan pentsatzea ahalbidetzen du. Bestetik, iraunkortasun kognitiboak arazo baten azterketa sistematikoa errazten du, eta arazoaren konponbideak aztertzearen ondorio gisa ere eratorri daiteke sormena. Bai malgutasuna bai iraunkortasuna eman daitezen, norbanakoak aktibaziomaila egokia izan behar du. Aktibazio kognitiboa helburu jakin bat lortzeko behar diren arreta eta esfortzu mailak mantentzeko motibazio-sistemen parte hartzeari dagokio, eta bat dator nerbio-sistema sinpatikoaren adierazleekin, esaterako odolaren presioa, metabolismoa edo bihotzaren erritmoarekin.

Segidan azaltzen den irudiak (5. irudia), eredu honetatik abiatuta aktibazio-mailak eta balentziak betetzen duten papera erakusten du.

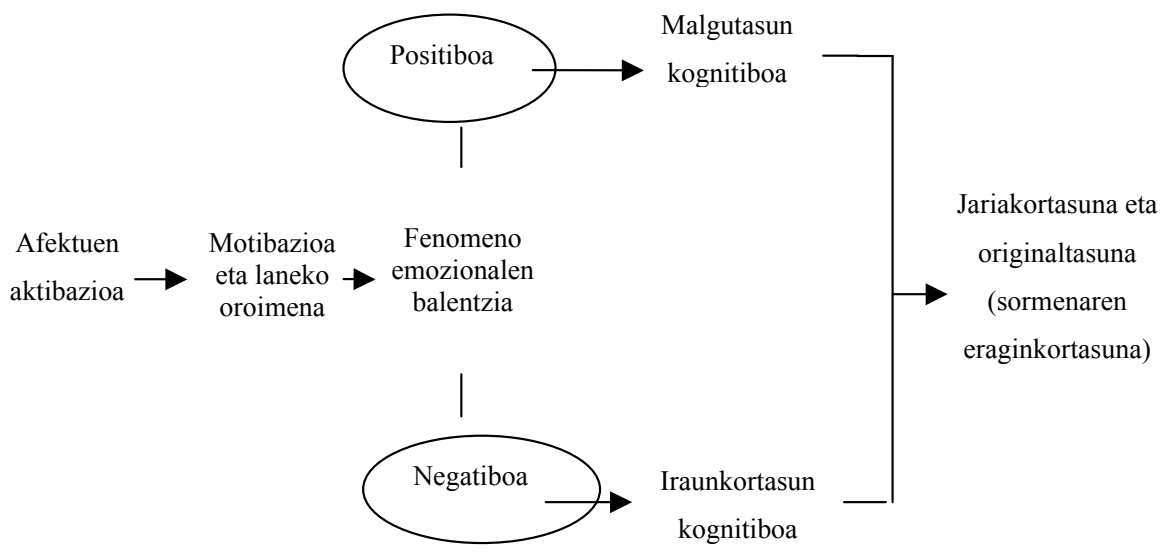

5. irudia

Sormenaren bide bikoitzaren eredua

(De Dreu et al., 2008: 742 or.) 
2. taula

Gogo-aldarteak, tonuaren, aktibazio-mailaren eta erregulazio-fokuaren arabera sailkaturik (De Dreu et al., 2008: 786 or.)

\begin{tabular}{|c|c|c|c|c|c|c|c|c|}
\hline \multirow{3}{*}{$\begin{array}{c}\text { Tonua } \\
\text { Aktibazio-maila } \\
\text { Erregulazio-fokua }\end{array}$} & \multicolumn{4}{|c|}{ Positiboa } & \multicolumn{4}{|c|}{ Negatiboa } \\
\hline & \multicolumn{2}{|c|}{ Desaktibazioa } & \multicolumn{2}{|c|}{ Aktibazioa } & \multicolumn{2}{|c|}{ Desaktibazioa } & \multicolumn{2}{|c|}{ Aktibazioa } \\
\hline & Prebentzioa & Promozioa & Prebentzioa & Promozioa & Prebentzioa & Promozioa & Prebentzioa & Promozioa \\
\hline Gogo-aldarteak & $\begin{array}{l}\text { Lasai, } \\
\text { erlaxaturik, } \\
\text { bare }\end{array}$ & & & $\begin{array}{l}\text { Alai, } \\
\text { grinatsu, } \\
\text { asaldaturik }\end{array}$ & & $\begin{array}{l}\text { Triste, } \\
\text { gogorik } \\
\text { eza }\end{array}$ & $\begin{array}{l}\text { Tentsioa, } \\
\text { ardura, } \\
\text { antsietatea, } \\
\text { beldurra }\end{array}$ & $\begin{array}{l}\text { Haserre, } \\
\text { frustra- } \\
\text { turik }\end{array}$ \\
\hline
\end{tabular}

Zehazki, gogo-aldarteak bost multzotan sailkatu dira eredu honetan (ikus 2. taula):

1. Tonu positiboa, desaktibazioa eta prebentziozko erregulazio-fokua (lasaitasuna, erlaxazioa, baretasuna). Aktibatu gabeko gogo-aldarteak, tonu negatiboa (adib. tristura) edo positiboa (adib. erlaxazioa) izanda ere, ez dira sormenarekin erlazionatzen, ez baitute sormenezko prozesuaren faseen (adib. ideia-sortze eta ebaluazioa) eraginkortasuna hobetzen, ez eta okertzen ere.

2. Tonu positiboa, aktibazioa eta promoziozko erregulazio-fokua (alaitasuna, grina, asaldadura). Aktibaturiko emozio positiboek kategorizazio-prozesuak errazten dituzte, kategorien arteko mugak apurtuz, euren edukia aberastuz eta antzeko elementuen parte-hartzea posible eginez. Bestalde, alaitasuna bezalako emozio positiboek malgutasun kognitiboa bultzatzen dute, ideien arteko asoziazioa eragiten dute eta estimulu berdin nahiz ezberdinen arteko erlazio anitzak ezartzea baimentzen dute, alderdi guzti horiek pentsamendu dibergentearekin lotura zuzena dutelarik. Aldiz, asaldadura edo euforia bezalako emozioek gehiegizko aktibazioa dutenean, zeregina azkar uztea eragin dezakete, baita erabakiak azkarregi hartzea eta akatsak egitea ere.

3. Tonu negatiboa, aktibazioa eta promoziozko erregulazio-fokua (haserrea, frustrazioa). Multzo honetan sailkatzen diren emozioek egoera jakin bat kontrolatzeko grina erakusten dute eta kontrola lortzera bideratzen dute energia guztia. Haserreak prozesatze analitikoa mugatzen du eta informazioa modu heuristikoan eta azalekoan lantzera darama, baita distrakziora ere. Gainera, haserre dauden pertsonek ez dute zeregin zehatz eta itxietan parte hartu nahi izaten. Beste modu batera esanda, haserreak pentsamendu diber- 
gentea, malgua, holistikoa eta analojikoa errazten du, baina soilik sormenezko prozesuaren hasieran, ez baitu prozesuan zehar irauten.

4. Tonu negatiboa, desaktibazioa eta promoziozko erregulazio-fokua (tristura, gogogabezia, desengainua). Tristura bezalako emozioek desaktibatu egiten gaituzte eta zerbaitekiko arreta eta gogoa galtzera eramaten gaituzte. Tristurak ezjakintasuna aztertzea du helburu, informazioa egituratuz eta sistematikoki aztertuz. Esaterako, informazioa modu algoritmikoan eta analitikoan prozesatzerakoan, kategoria zehatzetan kodetzerakoan eta arreta mantendu behar denean, tristura bezalako emozioak eraginkorrak dira, pentsamendu konbergentea, kritikoa, logikoa eta sistematikoa errazten baitute. Aldiz, tentsioarekin edo ardurarekin alderatuz, sormenezko prozesuan lortutako emaitzak ez lirateke hain eraginkorrak izango.

5. Tonu negatiboa, aktibazioa eta prebentziozko erregulazio-fokua (tentsioa, ardura, antsietatea). Tentsio edo antsietate maila egokiek pentsamendu konbergentea, kritikoa eta logikoa areagotzen dute, arreta konpondu beharreko arazoan zentratzen laguntzen dute. Portaerari dagokionez, gogo-aldarte horiek lagungarriak dira akatsak antzemateko eta egokiak kontzentrazio maila altuak eskatzen dituzten zereginetarako. Beraz, esan daiteke tristura bezalako emozioei tentsio puntua gehituz gero, pentsamendu konbergentea eta analitikoaren eraginkortasuna erraztu egiten dela.

\section{ONDORIO GISA}

Lan honetan zehar fenomeno emozionalen eta sormenaren arteko erlazioa azaltzen saiatu gara, bide batez, bi fenomeno horiek izan ditzaketen elkarreragina eta garrantzia ezagutzera emanez. Oro har, aztergai diren bi fenomenoen arteko denborazko erlazioa ezagutzerakoan, biak aldi berean gertatu daitezkeela ikusi da, baita fenomeno emozionalak sormenaren aurretik nahiz atzetik joan daitezkeela ere. Gainera, erregulazio-fokua promoziozkoa edo prebentziozkoa izanda ere, ikusi da aktibazio-maila ertaina dela sormena areagotzen edo eragozten duen aldagai nagusia.

Bestalde, bi fenomeno horien arteko elkarreraginean gehiago sakondu asmoz, sormenezko prozesuen parte diren alderdi kognitiboak eta afektibopertsonalak uztartu dituzten ikerlanak bildu dira. Ikerlan horietatik, xehetasun handiagoz deskribatu dira hezkuntza arlorako erabilgarrien izan daitezkeenak (Alfonso, 2000; Amabile et al., 2005; Averill, 1999; De Dreu et al., 2008; Zhou eta George, 2003). Aurkeztu diren ikerlan zein eredu teorikoek parekotasun asko dituzte euren artean, nahiz eta aditu ezberdinek garatu Dituzten. Funtsean, guztien arteko antzekotasunak honakoak dira: 1) Sormenaren lau alderdi nagusiak hartzen dituzte kontuan (produktua, 
prozesua, pertsona eta testuingurua); 2) Sormenean, era batera edo bestera, emozioen eragina azpimarratzen dute; 3) Emozioen eta sormenaren arteko erlazioa ikertuz, literatura zientifikoari ekarpen adierazgarriak egin dizkiete. Haatik, ikerlanok hiru puntutan ezberdintzen dira euren artean : 1) Sormenaren lau alderdietako zein/zeintzuk ikertu erabakitzerakoan (pertsona, prozesua, produktua edo testuingurua); 2) Sormenaren gaitasun kognitiboei eta emozionalei emandako pisuan; eta 3) Sormenaren eta emozioen arteko erlazioaren noranzkoan (aldi berean, emozioak aurretik edo ondoren).

Ondorioztatu daiteke, denborak aurrera egin ahala, emozioek sormenean duten paperari dagokion garrantzia ematen ari zaiola. Hala ere, aurrera begira, emozioen eta sormenaren arteko erlazioan sakontzen jarraitu beharko litzateke, ezin baitira bi fenomenoak isolaturik ulertu. Horrela, interesgarria litzateke emozioak eta sormena batera ikertzen, neurtzen eta garatzen dituzten eredu teorikoak, neurketa-tresnak eta esku-hartze programak diseinatzea, hezkuntza etapa bakoitzerak: Haur Hezkuntza, Lehen Hezkuntza, Bigarren Hezkuntza, Batxilergoa, Goi-mailako Hezkuntza eta Helduen Hezkuntza.

\begin{abstract}
Nowadays, the relationship between emotions and creativity constitutes a line of research of increasing interest. In addition, socio-emotional and creative skills are considered the cornerstone of improvement of academic achievement and job performance. Yet, an important issue still to be handled in deep is the relationship between emotional and creative phenomena. In this work, we put together the main contributions of the scientific literature on this issue. In the first part, the relationship between the emotional tone (positive or negative), the activation level (high, medium or low) and emotional regulation focus (promotion or prevention) are analyzed. In the second part, we present some of the most significant theoretical models investigating emotion-creative interaction defining, at the same time, their dimensions. In the third part, some recommendations are proposed for teachers or school tutors in order to improve their teaching-learning processes. Finally, some conclusions are elaborated and developed with the aim generating future research.
\end{abstract}

Keywords: Emotions, creativity, psychology, theoretical models. 
En la actualidad, la relación entre las emociones y la creatividad constituye una línea de investigación de creciente interés. Además, las habilidades socioemocionales y creativas son consideradas la piedra angular de la mejora del rendimiento académico y laboral. Pero, ¿cómo se relacionan los fenónemos emocionales y la creatividad? Este trabajo reúne las principales contribuciones que la literatura científica ofrece respecto a esta cuestión. En la primera parte, se analiza la relación entre el tono emocional (positivo o negativo), el nivel de activación (alto, medio o bajo) y los focos de regulación (de pomoción o de prevención). En la segunda parte, se presentan algunos de los modelos teóricos más significativos que investigan la interacción emoción-creatividad definiéndose, a su vez, sus dimensiones. En la tercera parte, se proponen algunas recomendaciones dirigidas al profesorado o a los/as tutores/as de cara a mejorar los procesos de enseñanza-aprendizaje. Por último, se elaboran y desarrollan algunas conclusiones con la vista fijada en la investigación futura.

Palabras clave: Emociones, creatividad, psicología, modelos teóricos.

De nos jours, la relation entre les émotions et la créativité est une ligne de recherche qui suscite l'intérêt général dans le domaine de la pédagogie. En plus, les habilités socio-émotionnelles et créatives sont considérées essentielles pour améliorer l'effectivité dans des contextes éducatifs et organisationnels. Mais d'abord, quel est le rapport entre les phénomènes émotionnels et la créativité? Ce travail réunit les principales contributions que la littérature scientifique offre à ce sujet. Dans la première partie, on analyse l'interaction entre le ton émotionnel (positif ou négatif), le niveau d'attraction (haut, moyenne ou faible) et les «sources» de régulation (de promotion et de prévention). Dans la deuxième partie, on présente les modèles théoriques les plus importants visant l'interaction émotion-créativité, et ses dimensions. Dans la troisième partie, on dresse quelques recommandations dirigées aux professeurs et aux tuteurs pour pouvoir améliorer l'apprentissage et l'enseignement. Finalement, on présente les conclusions extraites de ce travail.

Mots clé: Emotions, créativité, psychologie, modèles théoriques.

\section{ERREFERENTZIAK}

Akbari Chermahini, S. eta Hommel, B. (2012a). «More creative through positive mood? Not everyone!» Frontiers in Human Neuroscience, 6, 1-7. 
Alfonso, V. (2000). Un análisis de la interacción entre los componentes cognitivo y afectivo-personal de la creatividad. Valentziako Unibertsitateko doktore-tesia.

Amabile, T.M. (1983). The Social Psychology of Creativity. New York: SpringerVerlag.

Amabile, T.M. (1996). Creativity in context: Update to de Social Psychology of Creativity. Boulder, CO: West-view Press.

Amabile, T.M.; Barsade, S.; Mueller, J. eta Staw, B. (2005). «Affect and creativity at work». Administrative Science Quaterly, 50(3), 367-403.

Ashby, F.G.; Isen, A.M. eta Turken, A.U. (1999). "A neuropsychological theory of positive affect and its influence on cognition». Psychological Review, 106, 529-550.

Averill, J.R. (1999). «Individual differences in Emotional Creativity: Structure and Correlates». Journal of Personality, 67(2), 331-371.

Averill, J.R. eta Thomas-Knowles, C. (1991). «Emotional creativity». In K.T. Strongman (Arg.), International Review of Studies on Emotion (269299. orr.). London: Wiley.

Baas, M.; De Dreu, C.K. eta Nijstad, B.A. (2008). «A meta-analysis of 25 years of mood-creativity research: Hedonic tone, activation, or regulatory focus?». Psychological Bulletin, 134, 779-806.

Baas, M.; De Dreu, C.K. eta Nijstad, B.A. (2011). «When prevention promotes creativity: The role of mood, regulatory focus and regulatory closure». Journal of Personality and Social Psychology, 100(5), 794-809.

Baas, M.; Roskes, M.; Sligte, D.; Nijstad, B.A. eta De Dreu, C.K. (2013). «Personality and creativity: The dual pathway to creativity model and a research agenda». Social and Personality Psychology Compass, 7(10), 732-748.

Bar, M. (2009). «Predictions: A universal principle in the operation of the human brain». Philosophical Transactions of the Royal Society of London, 364, 1291-1300.

Bar-On, R. (1997). The Emotional Quotient Inventory (EQ-i): A test of emotional intelligence. Toronto: Multi-Health Systems.

Barsade, S. G. eta Gibson, D. (2007). «Why does affect matter in organizations? The academy of management perspectives». ARCHIVE, 21(1), 36-59.

Bradley, M.M. (2000). «Emotion and motivation». In J.T. Cacioppo, L.G. Tassinary eta G. Berntson (Arg.), Handbook of Psychophysiology (Bol. 2, 602642. orr.). New York: Cambridge University Press.

Byron, K.; Khazanchi, S. eta Nazarian, D. (2010). «The relationship between stressors and creativity: a meta-analysis examining competing theoretical models». Journal of Applied Psychology, 95(1), 201-212.

Carver, C.S. (2004). «Negative affects deriving from the behavioral approach system». Emotion, 4, 3-22.

Colzato, L.S.; Kool, W. eta Hommel, B. (2008). «Stress modulation of visuomotor binding». Neuropsychologia, 46(5), 1542-1548.

Conejero, S.; Pascual, A. eta Etxebarria, I. (2007). «Emozioei begirada psikologikoa». Uztaro, 63, 77-89.

Csikszentmihalyi, M. (1990). «The domain of creativity». In M.A. Runco eta R.S. Albert (Arg.), Theories of Creativity (190-212. orr.). Newbury Park, CA: Sage.

Damasio, A.R. (2001). «Some notes on brain, imagination, and creativity». In K. Pfenninger eta V.R. Shubik (Arg.), The origins of creativity (59-68. or.). Oxford, England: Oxford University Press. 
Davis, M.A. (2009). «Understanding the relationship between mood and creativity: A meta-analysis». Organizational Behavior and Human Decision Processes, 108(1), 25-38.

De Dreu, C.; Baas, M. eta Nijstad, B. (2008). «Hedonic tone and activation level in the mood-creativity link: Toward a Dual Pathway to Creativity Model». Journal of Personality and Social Psychology, 94(5), 739-756.

DeMoss, K.; Milich, R. eta DeMers, S. (1993). «Gender, creativity, depression and attributional style in adolescents with high academic ability». Journal of Abnormal Child Psychology, 21(4), 455-467.

Feist, G.J. (2014). «Psychometric Studies of Scientific Talent and Eminence». In D.K. Simonton (Arg.), The Wiley Handbook of Genius (62-86. orr.). Chichester, UK: John Wiley \& Sons, Ltd.

Feist, G.J. eta Barron, F.X. (2003). «Predicting creativity from early to late adulthood: Intellect, potential, and personality». Journal of Research in Personality, 37(2), 62-88.

Feldhusen, J.F. (1995). «Creativity: A knowledge base, metacognitive skills, and personality factors». The Journal of Creative Behavior, 29(4), 255-268.

Fernández-Abascal, E.G. (2008). Emociones Positivas. Madril: Editorial Pirámide.

Förster, J. eta Dannenberg, L. (2010). GLOMOsys: A systems account of global versus local processing. Psychological Inquiry, 21(3), 175-197.

Fredrickson, B.L. eta Branigan, C. (2005). «Positive emotions broaden the scope of attention and thought-action repertoires». Cognition and Emotion, 19, 313-332.

Fredrickson, B.L.; Cohn, M.A.; Coffey, K.A.; Pek, J. eta Finkel, S.M. (2008). «Open hearts build lives: Positive emotions, induced through loving-kindness meditation, build consequential personal resources». Journal of Personality and Social Psychology, 95(5), 1045-1062.

Frijda, N. eta Mesquita, B. (1994). «The social roles and functions of emotions». In S. Kitayama eta H.R. Markus (Arg.), Emotion and Culture: Empirical Studies of Mutual Influence (51-87. orr.). Washington, DC: American Psychological Association.

Gailliot, M.T.; Baumeister, R.F.; DeWall, C.N.; Maner, J.K.; Plant, E.A. eta Tice, D.M. (2007). «Self-control relies on glucose as a limited energy source: Willpower is more than a metaphor». Journal of Personality and Social Psychology, 92(2), 325-336.

Getz, I. eta Lubart, T. (1998). «The emotional resonance model of creativity: Theoretical and practical extensions». In S.W. Russ (Arg.), Affect, creative experience, and psychological adjustment (41-56. orr.). Brunner-Mazel Editions.

Gilet, A.L. eta Jallais, C. (2011). «Valence, arousal and word associations». Cognition and Emotion, 25(4), 740-746.

Goleman, D. (1995). Emotional Intelligence. New York: Bantam Books.

Goleman, D.; Boyatzis, R. eta McKee, A. (2002). El líder resonante crea más. El poder de la inteligencia emocional. Bartzelona: Plaza \& Janés.

Goleman, D.; Boyatzis, R. eta McKee, A. (2013). Primal Leadership: Unleashing the Power of Emotional Intelligence. Harvard Business Press.

Gotschke, T. (2006). «Affect modulation of selective attention and backgroundmonitoring». Invited talk presented at the Experimenteel Psychologische Onderzoeckschool (EPOS) symposium: Affective modulation of cognitive performance. Leiden, the Netherlands: Leiden University. 
Gruber, J.; Mauss, I.B. eta Tamir, M. (2011). «A dark side of happiness? How, when and why happiness is not always good». Perspectives on Psychological Science, 6(3), 222-233.

Herman, A. eta Reiter-Palmon, R. (2011). «The effect of regulatory focus on idea generation and idea evaluation». Psychology of Aesthetics, Creativity and the Arts, 5(1), 13-20.

Higgins, E.T. (2002). «How self-regulation creates distinct values: The case of promotion and prevention decision making». Journal of Consumer Psychology, 12, 177-191.

Ivcevic, Z.; Brackett, M. eta Mayer, J. (2007). «Emotional intelligence and emotional creativity». Journal of Personality, 75(2), 199-236.

Jamison, K.R. (1995). «Manic-depresive illness and creativity». Scientific American, 12-17.

Kaufmann, G. eta Kaufmann, A. (2014). «When good is bad and bad is good: Mood, bipolarity, and creativity». In J. Kaufman (Arg.), Creativity and Mental Illness (205-235. orr.). Cambridge: Cambridge University Press.

Kurman, J. eta Hui, C. (2011). «Promotion, prevention or both: Regulatory Focus and culture revisited». Online Readings in Psychology and Culture, 5(3), 1-16.

Lewis, M.; Haviland-Jones, J. eta Feldman, L. (2008). Handbook of Emotions. New York: The Guilford Press.

Martin, L.L. eta Stoner, P. (2014). «Mood as Input: What we think about how we feel determines how we think». In L. Martin eta A. Tesser (Arg.), Striving and Feeling: Interactions among Goals, Affect, and Self-regulation (279302. orr.). New York: Psychology Press.

Mayer, J.D. eta Salovey, P. (1997). «What is emotional intelligence?» In P. Salovey eta D. Sluyter (Arg.), Emotional development and emotional intelligence: Educational implications. New York: Basic Books.

Molden, D.C. eta Hui, C.M. (2011). «Promoting de-escalation of commitment: The regulatory focus perspective on sunk costs». Psychological Science, 22(1), 8-12.

Molden, D.C.; Lee, A.Y. eta Higgins, E.T. (2008). «Motivations for promotion and prevention». In J.Y. Shah eta W.L. Gardner (Arg.), Handbook of Motivation science (169-187. orr.). New York: Guilford Press.

Oatley, K.; Keltner, D. eta Jenkins, J. (2006). Understanding Emotions. Second Edition. Chichester, UK: John Wiley \& Sons, Ltd.

Pekrun, R. eta Linnenbrink-Garcia, L. (2014). International Handbook of Emotions in Education. New York: Taylor \& Francis.

Rathunde, K. (2000). «Broadening and narrowing in the creativity process: A commentary on Fredrickson's Broaden-and-build model». Prevention \& Treatment, 3(1), 1-12.

Repetto, E. (2003). «La competencia emocional e intervenciones para su desarrollo». In E. Repetto (Arg.), Modelos de Orientación e Intervención Psicopedagógica (454-482. orr.). Madril: UNED.

Runco, M.A. eta Jaeger, G.J. (2012). «The standard definition of creativity». Creativity Research Journal, 24(1), 92-96.

Russ, S.W. (1999). «An evolutionary model for creativity: does it fit?». Psychological Inquiry, 10(4), 359-361.

Russ, S.W. eta Schafer, E.D. (2006). «Affect in fantasy play, emotion in memories and divergent thinking». Creativity Research Journal, 18(3), 347-354. 
Russell, J.A. (1980). «A circumplex model of affect». Journal of Personality and Social Psychology, 39, 1161-1178.

Russell, J.A. eta Barrett, L. (1999). «Core affect, prototypical emotional episodes and other things called emotion: Dissecting the elephant». Journal of Personality and Social Psychology, 76(5), 805-819.

Salovey, P. eta Mayer, J.D. (1990). «Emotional intelligence». Imagination, Cognition and Personality, 9(3), 185-211.

Salovey, P.; Mayer, J.D. eta Caruso, D. (2002). «The positive psychology of emotional intelligence». In C.R. Snyder eta S.J. Lopez (Arg.), Handbook of Positive Psychology (159-171. orr.). Oxford, UK: Oxford University Press.

Shaw, E.D.; Mann, J.; Stokes, P.E. eta Manevitz, A. (1986). «Effect of lithium carbonate on associate productivity and idiosyncrasy in bipolar outpatients». American Journal of Psychiatry, 143, 1166-1169.

Simonton, D.K. (2008). «Creativity and genius». In L.A. Pervin, R.W. Robins eta O.P. John (Arg.), Handbook of Personality: Theory and Research (679701. orr.). New York: Guilford Press.

Soroa, G., Aritzeta, A. eta Balluerka, N. (2012). «Sormenaren lau alderdien berrikuspen teorikoa: prozesua, produktua, pertsona eta testuingurua». Uztaro, $85,73-96$.

Soroa, G., Balluerka, N., Aritzeta, A. eta Gorostiaga, A. (2012). «Adaptación y validación de la versión en euskara del Emotional Creativity Inventory (ECI) en jóvenes». In I. Montero, M.J. De Dios, B. Sierra eta Huertas, J.A. (Arg.), La investigación en motivación y emoción: Contribuciones de jóvenes investigadores en formación (45-57. orr.). Madril: EJIME.

Soroa, G., Gorostiaga, A., Aritzeta, A. eta Balluerka, N. (in press). «A shortened Spanish version of the Emotional Creativity Inventory (the ECI-S)». Creativity Research Journal.

Srivastava, S. eta Ketter, T.A. (2010). «The link between bipolar disorders and creativity: evidence from personality and temperament studies». Current Psychiatry Reports, 12(6), 522-530.

Sternberg, R.J. eta Lubart, T.I. (1991). «An investment theory of creativity and its development». Human Development, 34(1), 1-31.

Tierney, P. eta Farmer, S. M. (2002). «Creative self-efficacy: Its potential antecedents and relationship to creative performance». Academy of Management Journal, 45(6), 1137-1148.

To, M.L.; Fisher, C.D.; Ashkanasy, N.M. eta Rowe, P.A. (2012). «Within-person relationships between mood and creativity». Journal of Applied Psychology, 97(3), 599-612.

Wilson, T.D.; Centerbar, D.B.; Kramer, D.A. \& Gilbert, D.T. (2005). The pleasures of uncertainty: Prolonging positive moods in ways people do not anticipate. Journal of Personality and Social Psychology, 88(1), 5-21.

Winnicott, D. (1993). Exploraciones psicoanalíticas. Buenos Aires: Paidos.

Zenasni, F. eta Lubart, T.I. (2008). «Emotional traits moderate the impact of emotional state on creative performances». Journal of Individual Differences, 29(3), 157-167.

Zhou, J. eta George, J.M. (2003). «Awakening employee creativity: The role of leader emotional intelligence». The Leadership Quaterly, 14(4-5), 545-568. 